\title{
Conventionally bred papaya still possible, even in California
}

ommercial papaya production worldwide has been hurt by the plants' high susceptibility to papaya ringspot virus (PRSV), a disease transmitted by aphids that has swept through the tropics, beginning in India and Puerto Rico in the 1940s, moving to the main Hawaiian growing area in the 1970s, and Australia in the 1990s.

In the mid-1990s, scientists took a single gene from the virus itself and inserted it into the papaya's genetic code. That tiny change prevents the virus from making copies of itself and stops the disease from damaging fruit and killing the plants. Papayas are often held up as a classic success story for agricultural biotechnology (page 92). However, planting genetically engineered papayas is not the only way to skirt PRSV.

Last year, six UC Cooperative Extension farm advisors traveled to the Mexican state of Veracruz to gain a better understanding of Mexican production techniques, insect- and disease-control methods, and import-export issues in the tropical region. They found farmers using an unconventional papaya-production practice to successfully grow fruit that has not been genetically engineered.

At Rancho Neveria, a small farm near the city of Cardel, papaya is grown as an annual crop rather than a perennial tree, to manage the virus. Agronomist Honorio Fernández described the ranch's annual papaya-production system, from the soil mix for

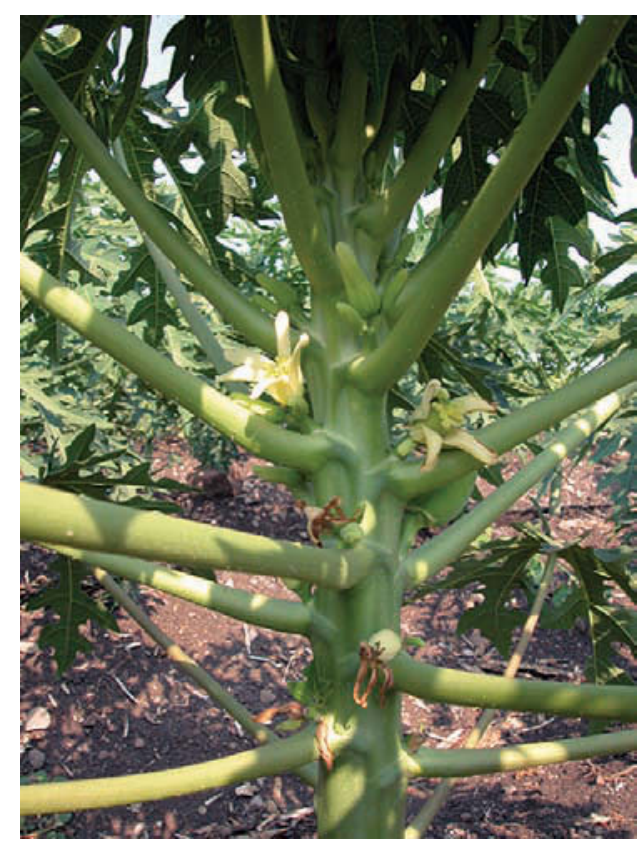

UC researchers believe there may be a market for papayas grown as an annual crop in California. seedlings to plant spacing in the field. The plants are started in a screen house (an enclosure to screen out insects) to protect them from disease-transmitting aphids. About 1,225 seedlings are transplanted per acre in the field, he said. Before harvest, a quarter of the plants are pulled due to viral infection. Nevertheless, the approximately 900 remaining plants produce a profitable crop before succumbing to disease.

Although California lies well outside the papaya's favored climate zone - between the Tropics of Cancer and Capricorn - this approach to papaya production could be profitable for the state's

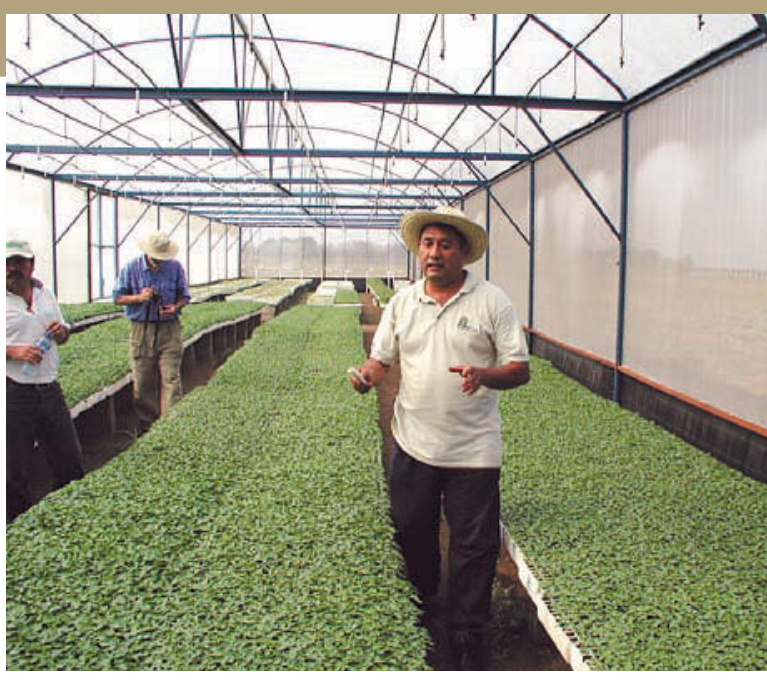

At a Mexican farm, Honorio Fernández explains how papaya is grown as an annual crop in order to manage the papaya ringspot virus. Thousands of seedlings are started in a screen house, above, and the survivors are transplanted to the field.

small-scale farmers.

UC Cooperative Extension farm advisor Manuel Jimenez is studying papaya production at the UC Kearney Research and Extension Center near Parlier. A typical San Joaquin Valley winter will kill the unprotected plant, squeezing the growing season between February and November. That time frame only allows the fruit to reach unripe maturity, but unripe papayas are suitable for cooking and popular with consumers of Asian descent. The unripe fruit may be baked like winter squash or pumpkin, or used for chutney. A group of marketers who visited KREC last year thought the locally grown fruit was good quality for the "green" market.

"We had Hmong, Burmese, Mexican, Japanese and Laotian papaya marketers prepare green papaya salads," Jimenez says. "They all prepared the papayas differently, but they were all delicious."

Jimenez grew several varieties of nongenetically engineered seed, and lost nearly all of the cultivars from Hawaii to PRSV. He said the Chinese plants showed more natural resistance. He was only able to harvest the green papayas for 3 weeks, not long enough for a fruit marketer to abandon the tropical papaya provider.

"Papaya is very inexpensive to grow," Jimenez says. "We can plant an acre for $\$ 20$ of seed, compared to several hundred dollars an acre for traditional vegetables. Papayas may be a crop for growers who direct-market their produce."

In fall 2004, Jimenez will try to protect the plants from cold weather under movable "hoop houses." If they survive the winter, the papaya fruit on those plants might ripen the following season, giving potential growers greater harvest flexibility and, perhaps, making papayas commercially viable for California small-scale farmers.

- Jeannette Warnert 